\title{
Development of Antibiotic Resistance Against Ureaplasma urealyticum Strains Isolated from Urogenital Samples
}

\section{Ürogenital Örneklerden Izole Edilen Ureaplasma urealyticum Suşlarına Karşı Antibiyotik Direnç Gelişimi}

\author{
Musa Saraçoğlu', Aşkın Eroğlu², Rauf Taner Divrik ${ }^{3}$ \\ 'Private Deniz Hospital, Clinic of Urology, İzmir, Turkiye \\ ${ }^{2}$ Başkent University İzmir Zübeyde Hanım Application and Research Center, Department of Urology, Izmir, Turkiye \\ ${ }^{3}$ Private Ege City Hospital, Clinic of Urology, İzmir, Turkiye
}

\section{What's known on the subject? and What does the study add?}

In this study, resistance of Ureaplasma urealyticum strains isolated from urogenital samples to antibiotics in 2001,2008 and 2013 is evaluated. Sensitivity to tetracycline and doxycycline was found to be continued at high rates. High resistance to ofloxacin and ciprofloxacin were observed.

\begin{abstract}
Objective: To assess any change in the antibiotic sensitivity of Ureaplasma urealyticum strains isolated from urogenital samples in the course of time. Materials and Methods: Hospital records were retrospectively examined and cases with growth of $U$. urealyticum in urogenital samples in the years 2008 and 2013 were identified. Furthermore, the change in the course of time was examined by taking into consideration the cases we reported in 2001. Results: Higher rates of sensitivity against tetracycline and doxycycline were observed in 60 patients with isolated $U$. urealyticum. Higher rates of resistance against ofloxacin and ciprofloxacin were observed. A significant difference was found in resistance against antibiotics when the records of 2008 and 2013 were compared. A statistically significant increase was found in resistance against ofloxacin and ciprofloxacin when the records of 2001 were compared with the records of 2008 and $2013(p<0.0005)$.

Conclusion: U. urealyticum strains demonstrated high levels of resistance to quinolones. Resistance development is increasing in the course of time. Sensitivity against tetracycline and doxycycline has continued at high rates. It would be beneficial to consider these results during empirical treatment to be applied in cases ineligible for culturing.

Keywords: Ureaplasma urealyticum, Resistance to quinolones, Urethritis

Öz

Amaç: Ürogenital örneklerden izole edilen Ureaplasma urealyticum suşlarının antibiyotiklere karşı duyarlılıklarının zaman içerisinde değişip değişmediğinin değerlendirilmesidir.

Gereç ve Yöntem: Hastane kayıtları retrospektif olarak incelenerek 2008 ve 2013 yılları içerisinde ürogenital örneklerde U. urealyticum üreyen olgular belirlenmiştir. Ayrıca 2001 yılında tebliğ ettiğimiz olgular göz önünde bulundurularak zaman içerisindeki değişim incelenmiştir.

Bulgular: U. urealyticum izole edilen 60 hastada tetrasiklin ve doksisikline karşı yüksek oranlarda duyarlılık gözlenmiştir. Ofloksasin ve siprofloksasine karşı direncin yüksek oranlarda olduğu gözlenmiştir. 2008 ve 2013 yılları karşılaştırıldığında antibiyotiklere karşı direnç oranlarında anlamlı bir farklıık gözlenmemiştir. 2001 yılı kayıtları 2008 ve 2013 yılları kayıtları ile karşılaştırıldığında ofloksasin ve siprofloksasine karşı direncin istatistiksel olarak anlamlı bir şekilde arttığı gözlenmiştir $(p<0,0005)$.

Sonuç: U. urealyticum suşları kinolonlara karşı yüksek oranda direnç göstermektedirler. Zaman içerisinde direnç gelişimi artmaktadır. Tetrasiklin ve doksisikline karşı duyarlılık yüksek oranlarda devam etmektedir. Kültür yapılamayan olgularda uygulanacak olan ampirik tedavide bu durumun göz önünde bulundurulması yararlı olacaktır.
\end{abstract}

Anahtar Kelimeler: Ureaplasma urealyticum, Kinolonlara direnç, Üretrit

Correspondence: Aşkın Eroğlu MD, Başkent University İzmir Zübeyde Hanım Application and Research Center, Department of Urology, İzmir, Turkiye Phone: +90 2322411032 E-mail: askineroglu@gmail.com ORCID-ID: orcid.org/0000-0003-2404-6209

Received: 17.10.2017 Accepted: 27.12.2017

Cite this article as: Saraçoğlu M, Eroğlu A, Divrik T. Development of Antibiotic Resistance Against Ureaplasma urealyticum Strains Isolated from Urogenital

Samples. J Urol Surg 2018;5(1):17-20.

๑Copyright 2018 by the Association of Urological Surgery / Journal of Urological Surgery published by Galenos Publishing House. 


\section{Introduction}

Ureaplasma urealyticum is a species belonging to the genus Ureaplasma and the family of Mycoplasmataceae in the order mycoplasmalates and class of Mollicutes of bacteria. Bacterial species U. urealyticum and Ureaplasma parvum under the Ureaplasma genus are found to be disease-causing agents in human beings (1).

This bacterium was initially recognized during the 1950's after being isolated in non-gonococcal urethritis cases (2). Later during the 1960's, it was renamed as T-mycoplasmas after its characteristics were better understood (3). Finally in 1974, the current name $U$. urealyticum was given on the basis of its impact on urea and other metabolic characteristics (4). Fourteen serotypes of $U$. urealyticum have been defined. Serotypes 1, 3, 6 , and 14 were defined as $U$. parvum since they are responsible more likely from gynecological and neonatal infections. However, other serotypes are still named as U. urealyticum (5).

U. urealyticum causes upper respiratory tract and lower urinary tract infections in humans. Urethritis, cystitis, epididymoorchitis, prostatitis, salpingitis and pelvic inflammatory disease are among the resulting diseases $(6,7)$. It is also suggested to increase risk of stone formation due to its urea breakdown effect (8). It is also known to be a significant risk for adverse pregnancy outcomes and complications of preterm birth (9). It may rarely be present in intra-articular fluids.

U. urealyticum does not grow in routine bacterial culture media. Specific culture media are used to detect this bacterium and implement antibiotic sensitivity tests. Although techniques, such as polymerase chain reaction, are used for diagnostic purposes, such methods do not provide any information on antibiotic sensitivity.

Absence of cell wall is the main specific characteristic of this family of bacteria. Therefore, antibiotics acting by impairing cell wall synthesis are not efficacious on this group of bacteria. Tetracycline, fluoroquinolone and macrolides are among the efficacious antibiotics. Development of resistance in particular against fluoroquinolone is observed in the course of time.

This study aims at assessing antibiotic sensitivity of $U$. urealyticum and the antibiotic resistance developing in the course of time.

\section{Materials and Methods}

This is a retrospective study. We analyzed the records of our hospital and identified the results positive for bacterium $U$. urealyticum in the samples taken from patients attended our urology unit in 2008 and 2013. The test reports were documented and examined.
Mycoplasma IST 2 test kit (BioMérieux, Marcy- I'Etoile, France) is used in our hospital for the diagnosis of Mycoplasma infections. This kit allows for both isolation of bacteria and sensitivity test against nine antibiotics.

Resistance against antibiotics was assessed, by comparing the test results obtained in 2008 and 2013 with the use of chisquare test. By this way, it was investigated whether or not there occurred any difference in antibiotic resistance within a period of five years.

\section{Statistical Analysis}

The results of these two years were compared with the rate of antibiotic resistance of $U$. urealyticum strains isolated within the first six months of 2000, as presented in 2001, and thus, the difference in resistance within a period of 14 years was also investigated. Chi-square test was used for this assessment. Samples (10) obtained in 2001 were examined using the Mycoplasma IST kit (BioMérieux, Marcy-l'Etoile, France) and sensitivity to seven antibiotics was tested.

\section{Results}

Results of 60 patients were accessible from the hospital records. 26 of these patients were tested in 2008, whereas 34 in 2013. The mean age of the patients was $37.9 \pm 11.4$ years (21-74). Twenty-five patients were female and all samples taken were urine.

Thirty-five patients were male and $U$. urealyticum was isolated from the urine of 7 patients and ejaculate of 28 patients.

Antibiotic sensitivity of the $U$. urealyticum strains isolated in 2008 and 2013 is given is Table 1. Among the nine antibiotics tested, highest sensitivity rates were observed in tetracycline and doxycycline and highest resistance rates in ofloxacin and ciprofloxacin. Resistance to ofloxacin was found in 12\%, whereas this rate was $62 \%$ for ciprofloxacin. No statistically significant difference was found in terms of the resistance rate against the nine tested antibiotics when data of 2008 and 2013 were compared ( $p>0.5$ ).

When the antibiotic resistance rate of the strains isolated in 2001 was compared with that of the strains isolated in 2008 and 2013; the increase in resistance to ofloxacin and ciprofloxacin was observed to be statistically significant $(p<0.0005)$. No statistical significant change was found in resistance against other antibiotics ( $p>0.5)$.

The rate of antibiotic resistance of $U$. urealyticum strains resulting from various studies are given in Table $2(10,11,12,13,14,15,16)$. This table, in particular, underlines the high level of resistance to fluoroquinolones. 
Table 1. Antibiotic sensitivity for U. urealyticum in 2008 and 2013 n (\%)

\begin{tabular}{|c|c|c|c|c|c|}
\hline \multirow[b]{2}{*}{ Antibiotic } & \multicolumn{3}{|l|}{2008} & \multicolumn{2}{|l|}{2013} \\
\hline & $\mathrm{S}$ & $\mathrm{I}$ & $\mathbf{R}$ & $\mathrm{S}$ & 1 \\
\hline Tetracycline & $26(100)$ & $0(0)$ & $0(0)$ & $34(100)$ & $0(0)$ \\
\hline Erythromycin & $22(84)$ & $3(12)$ & $1(4)$ & 31 (91) & $0(0)$ \\
\hline Clarithromycin & $22(84)$ & $2(8)$ & $2(8)$ & $30(88)$ & $1(3)$ \\
\hline Josamycin & $24(92)$ & $1(4)$ & $1(4)$ & $34(100)$ & $0(0)$ \\
\hline Pristinamycin & $23(88)$ & $1(4)$ & $2(8)$ & $34(100)$ & $0(0)$ \\
\hline Ofloxacin & $10(38)$ & $13(50)$ & $3(12)$ & $10(29)$ & $20(59)$ \\
\hline Ciprofloxacin & 1 (4) & $9(34)$ & $16(62)$ & $3(9)$ & $10(29)$ \\
\hline
\end{tabular}

S: Sensitive, I: Intermediate, R: Resistance

Table 2. Antibiotic resistance rates against Ureaplasma urealyticum as obtained in various studies (\%)

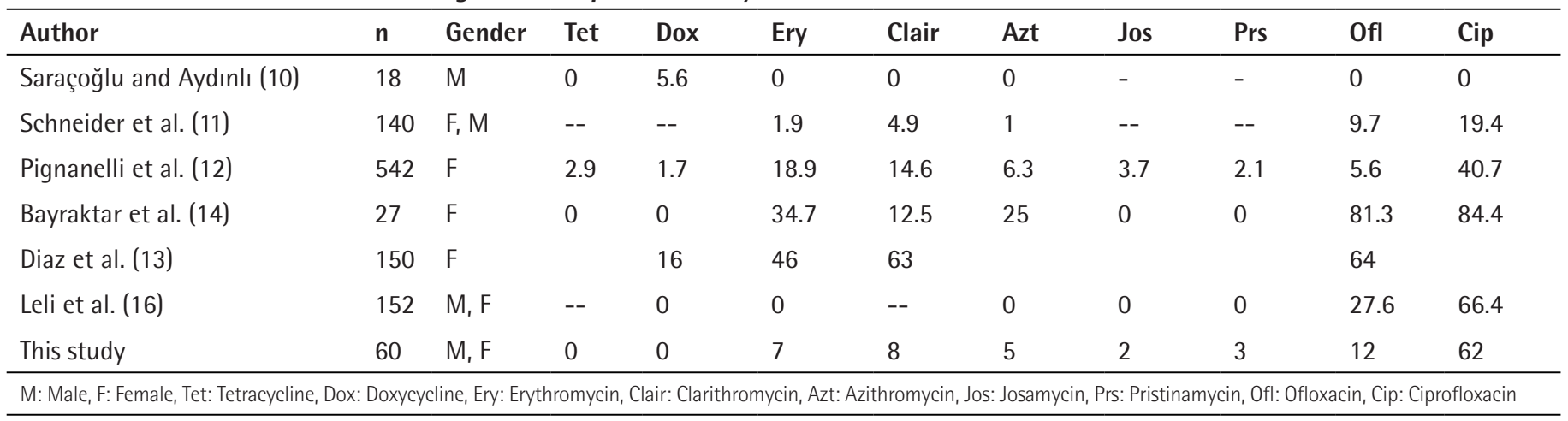

\section{Discussion}

$U$. urealyticum is a bacterium that potentially causes upper respiratory tract, lower urinary tract and genital system infections in adults. It is also known to play a role in neonatal infections. Inability of the growth of this bacterium in the routinely used culture media makes it difficult for isolation. Samples of increasing number of patients are isolated in the recent years thanks to the media, which are specially developed for the growth of this specific bacterium and are now in routine practice $(10,16)$.

$U$. urealyticum is innately resistant to certain antibiotics given its absence of bacterial cell wall. Beta-lactam antibiotics including penicillin and cephalosporin, glycopeptides including vancomycin and teicoplanin and phosphomycin are the antibiotics inefficacious against this bacterium. Furthermore, polymyxin, sulphonamide, trimethoprim, nalidixic acid and rifampicin are also not efficacious. When the above given matters are taken into consideration, it is understood that majority of the antibiotics used in empirical treatment in daily practice have no effect on $U$. urealyticum.

The main antibiotics efficacious on $U$. urealyticum are tetracyclines, macrolides, fluoroquinolones and pristinamycin.
Although fluoroquinolones are the most commonly used antibiotics, development of resistance to these antibiotics is a major concern.

In the recent 4 years, the incidence of $U$. urealyticum has been increasing continuously. Therefore, we wonder if the antimicrobial resistance of $U$. urealyticum and Mycoplasma hominis has changed. The fluoroquinolone resistance rate in Ureaplasma spp. varies widely among different countries and studies. For instance, in a recent study carried out in Switzerland, Schneider et al. (11) reported a rate of non-susceptibility to ciprofloxacin of $19.4 \%$, while in a recent study in Italy, $41 \%$ of isolates were ciprofloxacin-resistant (12). In our study, the rate of ciprofloxacin resistance was 62\%. Diaz et al. (13) reported that less than $35 \%$ of $U$. urealyticum isolates in Cuba were resistant to minocycline, pefloxacin, doxycycline, tetracycline, clindamycin, and azithromycin. They showed that the rate of resistance to ofloxacin, clarithromycin, and erythromycin were $64.3 \%, 63 \%$, and $46.1 \%$, respectively. In a study conducted in Turkiye on pregnant women, Bayraktar et al. (14) reported that the rate of resistance of genital mycoplasmas to doxycycline, josamycin, ofloxacin, erythromycin, tetracycline, ciprofloxacin, azithromycin, clarithromycin, and pristinamycin was $0 \%, 0 \%, 81.3 \%, 34.4 \%, 0 \%, 84.4 \%, 25 \%, 12.5 \%$, and $0 \%$, 
respectively, which was the report with the most similarity to our study. In their study conducted on South African pregnant women, Redelinghuys et al. (15) reported that susceptibility of Ureaplasma spp. to levofloxacin and moxifloxacin was $59 \%$ and $98 \%$, respectively. They showed that mixed isolates (Ureaplasma spp. and $M$. hominis) were highly resistant to erythromycin (97\%) and tetracycline (97\%).

Antibiotic resistance of $U$. urealyticum strains isolated from the urogenital samples obtained in 2001, 2008 and 2013 were investigated in this study. High rates of sensitivity to tetracycline and doxycycline were observed to continue. Resistance to ofloxacin and ciprofloxacin was found to be at high rates. High rates of resistance or these two antibiotics were also observed in other studies in the literature as summarized in Table 2.

\section{Study Limitations}

Due to low number of cases, patients were not sub-grouped according to gender, age and mode of sampling. It would be useful to investigate any potential difference in terms of antibiotic sensitivity among the sub-groups of gender, age groups and modes of sampling as urine, ejaculate, urethral discharge, vaginal discharge or cervical smear in larger series.

\section{Conclusion}

It would be beneficial to consider these sensitivity rates in the treatment of patients with suspected $U$. urealyticum infection but not eligible for culturing. Our study is important in terms of demonstrating a statistically significant increase in resistance to ofloxacin and ciprofloxacin within a period of 14 years.

\section{Ethics}

Ethics Committee Approval: Retrospective study.

Informed Consent: Retrospective study.

Peer-review: Externally peer-reviewed.

\section{Authorship Contributions}

Concept: M.S., Design: M.S., R. T.D., Data Collection or Processing: M.S., Analysis or Interpretation: A.E., M.S., Literature Search: R.T.D., A.E., Writing: M.S., A.E.

Conflict of Interest: No conflict of interest was declared by the authors.

Financial Disclosure: The authors declared that this study received no financial support.

\section{References}

1. Taylor-Robinson D. Infections due to species of Mycoplasma and Ureaplasma:an update. Clin Infect Dis 1996;23:671-682.

2. Shepard MC. The recovery of pleuropneumonia-like organisms from negro men with and without nongonococcal urethritis. Am J Syph Gonorrhea Vener Dis 1954;38:113-124.

3. Purcell RH, Taylor-Robinson D, Wong D, Chanock RM. Color test for the measurement of antibody to T-strain mycoplasmas. J Bacteriol 1966;92:6-12.

4. Shepard MC, Lunceford CD, Ford DK, Purcell RH, Taylor Rabinson D, Razın S Balck F. Ureaplasma urealyticum gen. nov., sp. nov: proposed nomenclature for the human T (T-strain) mycoplasma. Int J Syst Bacteriol 1974;24:160171.

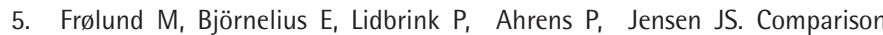
between Culture and a Multiplex Quantitative Real-Time Polymerase Chain Reaction Assay Detecting Ureaplasma urealyticum and U. parvum. PLoS One 2014;9:e102743.

6. Song T, Ye A, Xie X, Huang J, Ruan Z, Kong Y, Song J, Wang Y, Chen J, Zhang J. Epidemiological investigation and antimicrobial susceptibility an alysis of ureaplasma species and Mycoplasma hominis in outpatients with genital manifestations. J Clin Pathol 2014;67:817-820.

7. Wang OY, Li RH, Zheng LQ, Shang $\mathrm{XH}$. Prevalence and antimicrobial susceptibility of Ureaplasma urealyticum and Mycoplasma hominis in female out patients, 2009-2013. J Microbiol Immunol Infect 2016;49:359362

8. Grenabo L, Hedelin $\mathrm{H}$, Pettersson S. Urinary infection stones caused by Ureaplasma urealyticum: a review. Scand J Infect Dis Suppl 1988;53:46-49.

9. Viscardi RM. Ureaplasma species: role in diseases of prematurity. Clin Perinatol 2010;37:393-409.

10. Saraçoğlu M, Aydınlı A. Kronik prostatitli hastalarda mikrobiyolojik değerlendirme. 1. Genitoüriner enfeksiyonlar sempozyumu, 11-14 Ekim 2001 Antalya.

11. Schneider SC, Tinguely R, Droz S, Hilty M, Dona V, Bodmer T, Endimiani A 2015. Antibiotic susceptibility and sequence type distribution of Ureaplasma species isolated from genital samples in Switzerland. Antimicrob Agents Chemother 2015;59:6026-6031.

12. Pignanelli $S$, Pulcrano G, lula VD, Zaccherini P, Testa A, Catania MR. In vitro antimicrobial profile of Ureaplasma urealyticum from genital tract of childbearing-aged women in Northern and Southern Italy. APMIS 2014;122:552-555.

13. Diaz L, Cabrera LE, Fernandez T, Ibanez I, Torres $Y$, Obregon $Y$, Rivero $Y$. Frequency and antimicrobial sensitivity of Ureaplasma urealyticum and Mycoplasma hominis in patients with vaginal discharge. MEDICC Rev 2013;15:45-47.

14. Bayraktar MR, Ozerol IH, Gucluer N, Celik O. Prevalence and antibiotic susceptibility of Mycoplasma hominis and Ureaplasma urealyticum in pregnant women. Int J Infect Dis 2010;14:90-95.

15. Redelinghuys MJ, Ehlers MM, Dreyer AW, Lombaard HA, Kock MM. Antimicrobial susceptibility patterns of Ureaplasma species and Mycoplasma hominis in pregnant women. BMC Infect Dis 2014;14:171.

16. Leli $C$, Mencacci $A$, Bombaci JC, D'Alò F, Farinelli $S$, Vitali M, Montagna P, Bietolini C, Meucci M, Perito S, Bistoni F. Prevalence and antimicrobial susceptibility of Ureaplasma urealyticum and Mycoplasma hominis in a population of Italian and immigrant outpatients. Infez Med 2012;20:82-87. 